\title{
EDITORIAL
}

\section{LA NEFROLOGÍA EN EL HOSPITAL MILITAR CENTRAL DE BOGOTÁ: 50 AÑOS}

\author{
JORGE ECHEVERRI SARMIENTO, MD. ${ }^{1}$ \\ JUAN GUILLERMO VARGAS; MD. ${ }^{2}$ \\ ROBERTO D'ACHIARDI REY, MD, FACP
}

\begin{abstract}
${ }^{1}$ Internista - Nefrólogo Universidad Javeriana. Fellowship en Nefrología Crítica, Hospital de Austin, Melbourne. Especialista Medicina Crítica y Cuidado Intensivo, Fundación Universitaria Sanitas. Jefe del Servicio de Nefrología Hospital Militar Central y Unidad Renal Baxter - HMC. Nefrólogo y Coordinador de Nefrología Crítica Hospital Universitario San Ignacio. Profesor de Medicina Universidad Militar Nueva Granada y Pontificia Universidad Javeriana. Bogotá ${ }^{2}$ Internista - Nefrólogo Universidad El Bosque y Universidad Javeriana. Epidemiólogo Clínico, Universidad El Bosque. Especialista, Servicio de Nefrología, Hospital Militar Central y Unidad Renal Baxter - HMC. Profesor de medicina de la Universidad Militar Nueva Granada y la Universidad El Bosque. Bogotá.

${ }^{3}$ Internista - Nefrólogo: Universidad del Rosario, Universidad Militar Nueva Granada, University of Cincinnati. Nefrólogo Fundación Clínica Shaio. Nefrólogo Fundación Cardioinfantil y Unidad Renal Baxter Cardioinfantil. Profesor Titular de Medicina Universidad Javeriana. Profesor Clínico Principal Universidad de la Sabana.
\end{abstract}

\section{Introducción}

En el año 2012 se completan cincuenta años de la creación del servicio de nefrología del Hospital Militar Central (HMC) de Bogotá, y para conmemorar esta fecha hemos hecho una revisión de la historia de la nefrología en el HMC y el alto impacto que ha tenido en el desarrollo de la nefrología en Colombia.

El servicio de nefrología del HMC fue creado en 1962 por el maestro y profesor José María Mora Ramírez, previamente vinculado con el hospital desde 1955 como jefe del servicio de medicina interna, y después de realizar entrenamiento en nefrología en la Cleveland con Willem Kolff, padre del riñón artificial.

De acuerdo con lo anterior, durante estas cinco décadas, el servicio y quienes lo han integrado, han sido directriz y baluarte en el desarrollo de la nefrología colombiana, sobre la cual han ejercido profunda influencia y ha formado gran número de nefrólogos, que ejercen la especialidad en el país.

\section{Comienzo de la nefrología en Colombia}

Para ubicar dentro del marco mundial y nacional el comienzo de la nefrología en el HMC de Bogotá en 1962, debemos recordar que la especialidad nació como disciplina científica en 1960 durante el Primer
Congreso Internacional de Nefrología en Evian, Francia. En Norteamérica, después de un desarrollo lento de la nefrología por los años 40s, se definió como especialidad independiente a mediados de los 50 s y nació como subespecialidad con la creación de la National Kidney Foundation en 1960.

En forma casi simultánea, en la década de los 60s, se inició la nefrología como subespecialidad en Colombia. Ocho internistas colombianos se entrenaron por la misma época en nefrología en Estados Unidos y México y regresaron a Colombia para crear la subespecialidad. Uno de los primeros polos de desarrollo de la nefrología fue el HMC de Bogotá, bajo la dirección de Mora.

Mora contactó a Kolff a raíz de su visita a Colombia como profesor invitado a la Clínica Shaio en 1961, pues deseaba realizar entrenamiento en nefrología. Lo anterior se convirtió en un hecho, realizando el fellowship de nefrología bajo la dirección de Kolff, en el Departamento de Órganos Artificiales de la Cleveland Clinic Foundation y Western Reserve University. Regresó a Colombia en 1962 para ser el creador y primer jefe del servicio de nefrología del HMC, y constituirse, en nuestra opinión, en el padre de la nefrología en Colombia.

Pocos meses o años después llegaron otros especialistas a crear los servicios de nefrología de los hospitales 
San Juan de Dios de Bogotá, San Vicente de Paúl de Medellín y Universitario del Valle, este último hacia 1965. Tres ciudades, cuatro centros hospitalarios y ocho reconocidos nefrólogos fueron la base estructural de la nefrología en Colombia en los años 60s, siendo claro que muchos de ellos como el doctor Jaime Borrero Ramírez en Medellín y el mismo Mora en Bogotá, ya habían dado pasos en la atención de enfermedades renales en Colombia, antes de salir a especializarse.

La Sociedad Colombiana de Nefrología, hoy Asociación Colombiana de Nefrología e Hipertensión Arterial, se creó en 1966 en Bogotá. Del grupo del HMC y sus egresados, fueron presidentes de la Sociedad los doctores José María Mora Ramírez, Hernán Torres Iregui, Eduardo Carrizosa Alajmo, Roberto D'Achiardi Rey y Germán Gamarra Hernández.

\section{Nefrología en el Hospital Militar Central de Bogotá}

El servicio de nefrología del HMC, el primero creado en el país, lo inició José María Mora, quien fue su jefe entre 1962 y 1970 , cuando fue nombrado jefe del departamento de medicina interna. Fue reemplazado por Hernán Torres, también entrenado en nefrología en la Cleveland Clinic, quien ocupó la jefatura del servicio de 1970 a 1977, cuando a su vez fue nombrado jefe del departamento de medicina interna.

En 1973 Torres creó el programa de entrenamiento en nefrología en el HMC, de dos años de duración, avalado por la Sociedad Colombiana de Nefrología, cuando aún la especialidad no era reconocida en Colombia. De hecho, por esa época, la Sociedad de Nefrología nos otorgaba el diploma como miembros de número, que era la credencial que se utilizaba para el ejercicio de la nefrología en Colombia.

En 1975 egresó Eduardo Carrizosa, primer nefrólogo de escuela entrenado en Colombia, quien fue llamado a crear la especialidad y a su vez, creó la tercera escuela de nefrología del país en 1.981 en el Hospital Universitario San José con la Universidad del Rosario, hoy con la Fundación Universitaria de Ciencias de la Salud.

En 1978 fue nombrado como jefe del servicio de nefrología Juan Daniel Ordoñez Ordoñez, entrenado en nefrología en Louisiana State University, quien venía del Charity Hospital New Orleans, y ocupó la jefatura hasta 1981, cuando regresó a Estados Unidos para vincularse con la Kayser Foundation en Oakland, California.

En 1977 egresó el segundo nefrólogo de la escuela del HMC: Roberto D'Achiardi, quien se vinculó con el servicio de nefrología de la institución y luego realizó el Fellowship en nefrología en el Cincinnati General Hospital y la Universidad de Cincinnati con Victor Pollak, regresando en 1982 como jefe del servicio de nefrología del HMC. Hacía 1982 se aprobó la especialidad del HMC y la Escuela Militar de Medicina por la Ascofame, la primera especialidad de nefrología aprobada en Colombia. En marzo de 1.988 pasó al Hospital Universitario San Ignacio y la Pontificia Universidad Javeriana, a dirigir el servicio de nefrología, y ese mismo año creó la quinta escuela de nefrología del país, aprobada oficialmente en 1990.

La segunda escuela de nefrología en el Hospital San Vicente de Paúl de Medellín, con la Universidad de Antioquia, la creó en 1975 Jaime Borrero.

La cuarta fue creada en el Hospital Universitario del Valle con la Universidad del Valle, por Álvaro Mercado Juri.

Los otros tres postgrados de nefrología del país fueron creados así: la sexta escuela en 1998 en el Hospital Clínica San Rafael con la Escuela de Medicina Juan N. Corpas por Mauricio Sanabria Arenas, egresado de la escuela del HMC; la séptima escuela en la Fundación Cardioinfantil con la Universidad del Rosario en 1999 por Jesús Muñoz Silva y la última, por Mauricio Uribe Betancur Medellín en 2001, en la Clínica Universitaria Bolivariana, hoy en el Hospital Pablo Tobón Uribe con la Pontificia Universidad Bolivariana.

Continuando con la historia del servicio de nefrología del HMC, desde 1988 hasta cerca del 2000 ocupó la jefatura del servicio María Elvira Martínez Rondanelli, luego nombrada subdirectora científica del HMC, siendo reemplazada en la dirección por Manuel Ruiz. Finalmente, desde 2008 la unidad renal funciona en convenio con Baxter, siendo inaugurada una moderna unidad renal en enero 19 de 2009. Fueron jefes del servicio entre 2007 y 2009 Hildebrando Leguizamón Sendoya, nefrólogo egresado de la Universidad Javeriana y José Manuel Arboleda Vallecillas, egresado del HMC. 
Desde julio de 2010 el servicio de nefrología está dirigido por Jorge Echeverri Sarmiento, egresado de la Pontificia Universidad Javeriana y del Hospital Universitario San Ignacio, con estudios de postgrado en 2009 en Cuidado Crítico en el Hospital de Austin, en Melbourne, con Rinaldo Bellomo; con la colaboración de Juan Guillermo Vargas, también egresado de la Universidad Javeriana.

\section{Nefrólogos egresados}

Al principio los nefrólogos se formaron en el HMC, que es Centro Médico de Estudios para Graduados y años después, luego de la aprobación oficial del postgrado de nefrología en el país, con la Escuela Militar de Medicina, hoy Universidad Militar Nueva Granada han egresado 48 nefrólogos; después de Eduardo Carrizosa y Roberto D'Achiardi, egresaron en su orden Germán Gamarra, Germán Durán, Álvaro Ordóñez, Gustavo Aroca, Carlos Prada, Ramón Duque, Luis Castillo, Hernando Giovanetti, John Serna, Andrés Díaz, Mauricio Sanabria, Enrique Klahr, Martha Medina, Robert Briceño, Rafael Rodríguez, Hernando González, Mauricio Nieto, Iván Nieto, Manuel Soto, Armando Ramos, Ignacio Villanueva, Amalfi Charry, Erika Yama, Amable Durán, Andrés Soto, David Camargo, Yelma Osorio, Layla Tamer, Amauri Ariza, Manuel Ruiz, Edgar Tinjacá, Jorge Van Arken, José Manuel Arboleda, Luis Cano, Luis A Cely, Elkin Machacón, Jesús Morales, Edwin Hernandez, Jose Javier Ayala, Fredis Miguel Baloco, Jorge Antonio Mora, Sonia Celis, Fabián Barrios, Rodrigo Daza, Mario Javier Serna y César Mercado. Todos ellos ejercen la nefrología con los más altos estándares científicos, éticos y personales en diversas ciudades del país. Se encuentran actualmente en entrenamiento 4 fellows: Mauricio Moreno, Gustavo Quiróz, Jaime Echenique y Alejandro Camargo.

\section{Nefrología pediátrica}

El desarrollo de la nefrología pediátrica en el HMC fue en cierta forma paralelo con el de la nefrología de adultos, $y$ ha desempeñado un papel importante en el país. El servicio lo creó Jorge de la Cruz París en 1961, después de entrenarse en México con Gustavo Gordillo Paniagua; luego de la Cruz entrenó a Erika Cuervo, quien fue jefe del servicio entre 1977 y 1980 , siendo reemplazada por Ricardo Gastelbondo Amaya, también entrenado en México por Gordillo, quien fue jefe desde 1980 hasta el 2000, cuando se retiró, siendo reemplazado por Oscar Hernández Rodríguez, quién ejerce la jefatura hasta el día de hoy.

Gastelbondo fundó la primera escuela de nefropediatría en Colombia con la Universidad del Bosque en la Fundación Cardioinfantil, la cual se aprobó en el año 2000 y recibió residentes a partir del 2002, la primera Luz Stella González. Luego, en forma casi simultánea, se creó la escuela de nefropediatría en Medellín, por Juan José Vanegas en el Hospital Pablo Tobón Uribe, con la Pontificia Universidad Bolivariana.

\section{Diálisis peritoneal aguda}

Dentro del establecimiento formal de la nefrología clínica en Colombia, José María Mora realizó en 1962 la primera diálisis peritoneal aguda (DPA) en el HMC, modalidad de terapia que se continúo haciendo en forma rutinaria en pacientes con insuficiencia renal aguda, por esa época con técnica estándar, catéter rígido, sistema abierto utilizando el liquido de diálisis en botellas y luego en bolsas de plástico, con tecnología Travenol. Desde esa época, otras instituciones hospitalarias del país iniciaron el programa, utilizando la misma técnica hasta finales de los 80 s, cuando las casas farmacéuticas dejaron de producir los catéteres rígidos, lo cual contribuyó al abandono de la DPA, hasta años recientes, cuando se está volviendo a utilizar esta opción terapéutica en IRA, con base en los mismos insumos que se usan para diálisis peritoneal crónica (DPC), la cual se está realizando en el HMC nuevamente desde el 2008.

Se debe anotar que en Colombia las primeras DPAs con tecnología "paisa" las realizaron en Medellín hacia 1960 Álvaro Toro Mejía y Jaime Borrero.

\section{Diálisis peritoneal crónica}

La DPC en la modalidad de diálisis peritoneal ambulatoria continua (DPAC), se inició en el Hospital San Vicente de Paúl de Medellín por el grupo de Jaime Borrero hacía marzo de 1981, y varios meses después por los grupos de Eduardo Carrizosa en el Hospital San José y de Roberto D'Achiardi en el HMC de Bogotá. Luego se empezó a convertir en terapia rutinaria para el manejo de pacientes con enfermedad renal crónica en el país. Desde 1994 contamos con la diálisis peritoneal automatizada (DPA). En 2008 la población de pacientes prevalentes en DPC era de 6.478. Con una población de más de 46.294.841 
habitantes, se calcula que en la actualidad podría haber cerca de 22.000 pacientes en diálisis crónica, de los cuales cerca del $40 \%$ reciben DPC.

\section{Hemodiálisis aguda}

Mora trajo los primeros riñones artificiales Kolff a Colombia para el HMC y la Clínica Shaio de Bogotá. Realizó la primera hemodiálisis aguda (HDA) en Colombia a un adolescente, hoy en día médico cardiólogo, quién presentó IRA después de una cirugía de coartación de aorta en la Clínica Shaio en junio de 1963. Le colaboró en este primer procedimiento el cardiólogo Gustavo Restrepo, quién había recibido entrenamiento temporal en nefrología en Cleveland, mientras esperaba iniciar el postgrado de cardiología. Como dato anecdótico, no siendo el agua apta para realizar la diálisis, fue necesario llamar el carro de bomberos que suministró el agua de mejor calidad para la época y localidad, a través de una ventana del segundo piso, teniendo el vehículo que aguardar dos horas para suministrar el agua para el siguiente cambio. Lo anterior, porque en esa época se llenaba el tanque de la "olla", como se llamaba popularmente el riñón de Kolff, con 120 litros, que era necesario cambiarlos a las dos horas, para poder completar las cuatro horas de diálisis.
En el HMC, Mora realizó la primera HDA el 6 de agosto de 1963, en una habitación del sexto piso, diagonal a su oficina, habilitada para tal efecto, sitio donde se realizaron muchas hemodiálisis agudas ( $\mathrm{Fi}-$ gura 1) hasta inaugurar la unidad renal en el segundo piso del hospital. Luego lo hicieron Enrique Carvajal Arjona y su grupo en el Hospital San Juan de Dios de Bogotá y Jaime Borrero y Álvaro Toro en el San Vicente de Paúl de Medellín.

Por esa época, una vez se decidía la diálisis, el nefrólogo colocaba quirúrgicamente el shunt de Schribner, por lo regular en el antebrazo, el cual se coagulaba $e$ infectaba con relativa facilidad. Luego y durante varios años se utilizaron dos catéteres vasculares colocados por punción en la vena femoral, que se retiraban después de cada procedimiento, e incluso se reutilizaban varias veces, dejándolos en solución de formol y años después en cidex en el período intermedio. Se preparaba la solución de diálisis para el riñón de Kolff, con base en 120 litros de agua a los cuales se agregaba sal $600 \mathrm{~g} /$ litro, azúcar $750 \mathrm{~g}$ / litro, bicarbonato $250 \mathrm{~g} /$ litro, cloruro de potasio, calcio y magnesio, en fin "toda una receta de cocina", que luego se mezclaba con una vara de plástico. $\mathrm{Si}$ por error se alteraba el orden de colocación de los ingredientes, estos elementos se precipitaban y era

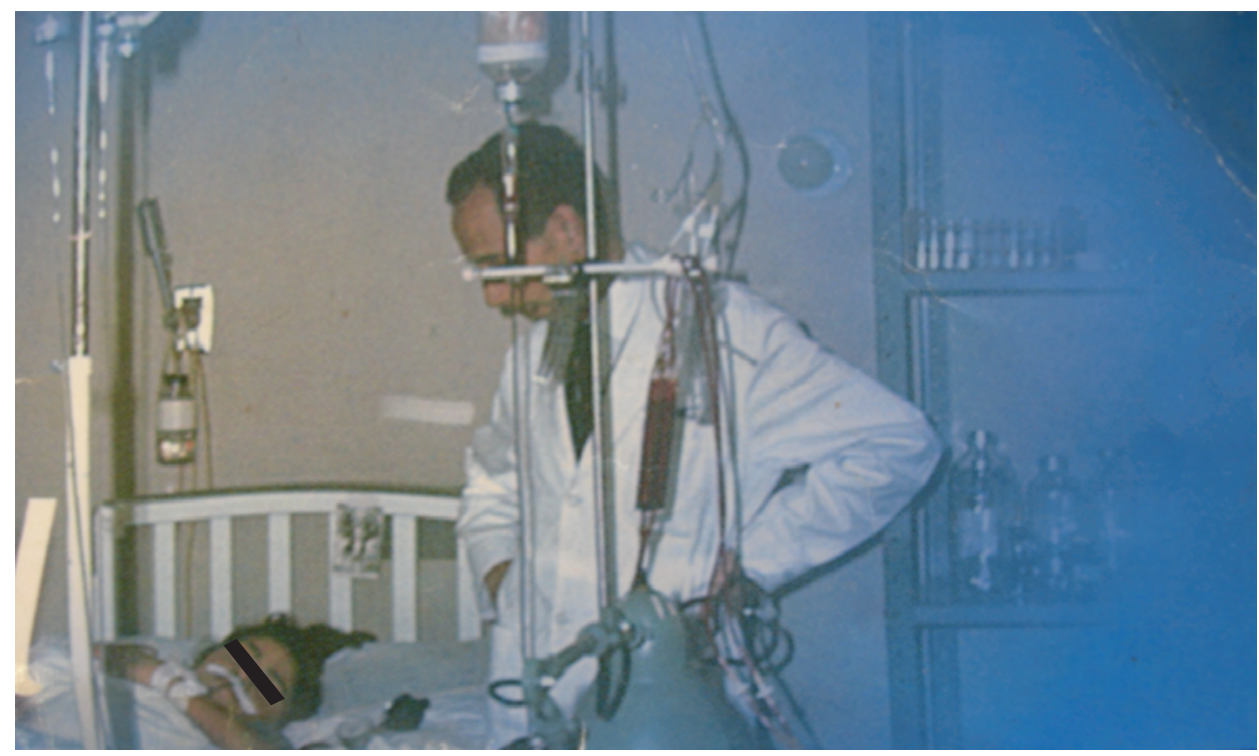

Figura 1. Hemodiálisis aguda realizada en el HMC de Bogotá en los años sesenta por el Dr. José María Mora. 
necesario desocupar el tanque y volver a empezar. A las dos horas de la HDA, se desocupaba el tanque y se preparaba de nuevo la solución de diálisis para las dos horas restantes.

Se conectaba el paciente regularmente hacia la 7 y se terminaba de dializar después de las 12 de la noche, al principio sin contar con la colaboración de enfermería. Al terminar se retiraban los catéteres y se hacía limpieza del riñón artificial. Lo anterior contrasta con el manejo actual de la insuficiencia renal aguda, con tecnología moderna, siendo su tratamiento con HDA una rutina, la cual persistirá a través del tiempo, con tecnología cada vez mejor, junto con las diversas opciones terapéuticas actuales de terapias de reemplazo renal continuo (TRRC).

\section{Terapias de Reemplazo Renal Continuo}

Además del manejo rutinario del paciente con insuficiencia renal aguda con HDA y DPA, se dispone en la actualidad de diversas modalidades de TRRC, como son hemofiltración venovenosa continua, hemofiltración de alto volumen, hemodiafiltración, ultrafiltración aislada, de las cuales ya se habían realizado varios procedimientos en el HMC, pero que en la actualidad, especialmente desde el año 2010, bajo la dirección de Jorge Echeverri, se están realizando en forma rutinaria con más de 200 procedimientos al año. De igual forma, se están utilizando otro tipo de técnicas de aclaramiento extracorpóreo en los pacientes del $\mathrm{HMC}$ con patologías autoinmunes, tal es el caso de la plasmaféresis ó intercambio plasmático con mas de 50 intervenciones en el último año.

\section{Hemodiálisis crónica}

Entre 1956 y 1960 se generalizó la hemodiálisis crónica (HDC) como modalidad de terapia para enfermedad renal crónica, favorecida por invenciones como el shunt de Schribner en 1960 y la fístula arteriovenosa de Brescia y Cimino en 1964 en Nueva York.

En Colombia, la HDC se inició hacía 1967 en Medellín. Allí por demás diseñaron el riñón GRACEC (Graciela y Cecilia), por el nombre de las dos primeras pacientes que lo utilizaron; así mismo en el Hospital San Juan de Dios de Bogotá, seguidos por Torres en el HMC de Bogotá en 1971, institución donde como dato anecdótico, se utilizó transitoriamente un riñón artificial hecho en Colombia por el Ingeniero Jorge Reynolds para un allegado que se dializaba en la casa.

En la actualidad en la unidad Renal del HMC se dispone de 28 puntos para riñones artificiales de última tecnología, realizando diálisis crónica y seguimiento de cerca de 160 pacientes al mes.

\section{Trasplante renal}

En 1953 el grupo de Hamburger realizó el primer trasplante de donante relacionado en París y en junio de 1954 el grupo de Merrill el primer trasplante de gemelos idénticos en Boston.

En Colombia, el pionero de trasplante renal fue Enrique Carvajal Arjona y su grupo en el Hospital San Juan de Dios de Bogotá, que realizó en 1965 los cuatro primeros trasplantes de cadáver en Colombia. Luego se creó el primer programa regular de trasplante renal en el Hospital San Vicente de Paúl de Medellín, por el grupo de Borrero, Toro y Jorge Luis Arango Acosta, quienes realizaron el primer trasplante renal el 29 de Agosto de 1973. Este grupo continúa trasplantando activamente y ha tenido la colaboración de Mario Arbeláez Gómez, Gonzalo Mejía y Jorge Henao, entre otros, en el transcurso del tiempo.

En 1978 se creó el segundo programa de trasplante renal del país en el HMC, con Torres, Mora, D'Achiardi y Ordoñez, siendo los cirujanos vasculares Víctor Caicedo Ayerbe, Wilde Jiménez Urbano y Gilberto Clavijo Contreras y los urólogos Jesús Guzmán Charry y Jaime Cajigas Rodríguez, equipo multidisciplinario que trabajo en forma organizada y eficiente durante cerca de 10 años, hasta 1988.

El primer trasplante de cadáver se realizó en forma urgente, un fin de semana, en un árbitro de fútbol quien se estaba quedando cuadriparético por neuropatía secundaria a la enfermedad renal crónica, quién después de algunas complicaciones salió del hospital y tuvo riñón funcional por varios años. Luego se crearon otros grupos de trasplante en Colombia que han realizado mas de 3.500 trasplantes a nivel del país.

\section{Consulta pre diálisis}

En el HMC existió por muchos años, cuando ese modelo de atención no se utilizaba en la práctica clínica 
regular, una clínica de hipertensión arterial creada por Torres, que funcionó durante varios años, y en la actualidad, existe la clínica de consulta pre diálisis que atiende cerca de 200 pacientes, aportando a la formación de médicos generales y residentes con educacion en temas de promoción de salud renal, prevención y tratamiento de la ERC en todos sus estadíos.

\section{Bibliografía}

Borrero J. Apuntes a la historia de la nefrología en Colombia. Comunicación personal. No publicado. 1999.

Carvajal E. Alotrasplantes renales. Revista Médica, Órgano de la Academia Nacional de Medicina 1967; 3-18.

D'Achiardi R, Latorre J. El Trasplante renal. Revista Javeriana 1988; 551: 45-51.
D'Achiardi R. Sociedad Colombiana de Nefrología y la especialidad en Colombia. Boletín ACMI. 1992; 4: 2.

D'Achiardi R. Reseña histórica de la nefrología en Colombia. Boletín Sociedad Colombiana Nefrología. 1992; 1:1-3.

D'Achiardi R, Mora JM, La nefrología en Colombia, pasado, presente y futuro. En Perspectivas en Nefrología, C López y H Altahona, editores; Editorial Ex Libris, Primera edición, $2.000 \mathrm{pp} \mathrm{1-24}$

D'Achiardi R. José María Mora Ramírez MD, FACP. Padre de la nefrología en Colombia. Revista Colombiana de Nefrología e Hipertensión Arterial 2008; 1: 256-257.

Gamarra G. Unidad de Nefrología. Revista UIS Medicina 1987; 15: 49-50.

Klahr S. The early days of the nephrology in Colombia. Kidney Int; 2006; 69: 199-200. 


\title{
EDITORIAL
}

\section{NEPHROLOGY AT HOSPITAL MILITAR CENTRAL OF BOGOTÁ: 50 YEARS}

\author{
Jorge ECHEVERRI SARMIENTO, MD. ${ }^{1}$ \\ JUAN GUILLERMO VARGAS; MD. ${ }^{2}$ \\ ROBERTO D'ACHIARDI REY, MD, FACP
}

\begin{abstract}
${ }^{1}$ Internist - Nephrologist Universidad Javeriana. Critical Nephrology Fellow, Austin Hospital, Melbourne. Critical Medicine and Intenvive Care Specialist, Fundación Universitaria Sanitas. Chief of the Nephrology Divison at Hospital Militar Central and Baxter Renal Unit - HMC. Nephrologist and Coordinator of Critical Nephrology, Hospital Universitario San Ignacio. Professor or Medicine, Universidad Militar Nueva Granada and Pontificia Universidad Javeriana. Bogotá.

${ }^{2}$ Internist - Nephrologist Universidad El Bosque and Universidad Javeriana. Clinical Epidemiologist, Universidad

El Bosque. Nephrology Division Specialist, Hospital Militar Central and Baxter Renal Unit - HMC. Professor of Medicine, Universidad Militar Nueva Granada and Universidad El Bosque. Bogotá.

${ }^{3}$ Internist - Nephrologist: Universidad del Rosario, Universidad Militar Nueva Granada, University of Cincinnati. Nephrologist Fundación Clínica Shaio. Nephrologist Fundación Cardioinfantil and Cardioinfantil Baxter Renal Unit. Titular Professor of Medicine, Universidad Javeriana. Leading Clinical Professor, Universidad de la Sabana.
\end{abstract}

\section{Introduction}

In 2012, the Division of Nephrology at Hospital Militar Central (HMC) of Bogotá will complete fifty years of its creation and to commemorate this date we have carried out a review of the history of the Nephrology Division at HMC and the high impact it has had on the development of the nephrology in Colombia.

The Division of Nephrology at HMC was created in 1962 by the teacher and professor José María Mora Ramírez, formerly linked to the hospital since 1955 as Chief of the Internal Medicine Department and after receiving training in nephrology at Cleveland Clinic with Willem Kolff, father of the artificial kidney. According to the aforementioned, during these five decades the department and those who have constituted it have been guidelines and bastions in the development of Colombian nephrology which they have deeply influenced, and have shaped a great deal of nephrologists who have their specialty practice in the country.

\section{Initiation of the Nephrology in Colombia}

In order to locate the initiation of the nephrology at HMC of Bogotá in 1962 within the worldwide and national setting, we should remember that the specialty was born as a scientific discipline in 1960 during the first International Nephrology Congress in Evian, France. In North America, after a slow development of the nephrology by the 1940s, it was defined as an independent specialty by the mid-1950s and was born as a subspecialty with the creation of the National Kidney Foundation in 1960.

Almost simultaneously, in the 1960s decade, the nephrology as a subspecialty was initiated in Colombia. By the same time, eight Colombian internists were trained in nephrology in the United States and Mexico and returned to Colombia to create the subspecialty. One the first poles of the development of the nephrology was the HMC of Bogotá, under Dr. Mora's direction.

Mora contacted Kolff after his visit to Colombia as invited Professor to the Clínica Shaio in 1961, since he wished to be trained in nephrology. It became reality and he obtained his nephrology fellowship headed by Kolff in the Department of Artificial Organs of Cleveland Clinic Foundation and Western Reserve University. He returned to Colombia in 1962 and became the creator and first chief of the Division of Nephrology at HMC and gets to be, in our opinion, the father of the nephrology in Colombia.

A few months or years later, other specialists arrived to create the departments of nephrology at the hospital 
San Juan de Dios of Bogotá, San Vicente de Paúl of Medellín and Universitario del Valle, the latter by 1965. Three cities, four hospital centers and eight acknowledged nephrologists were the foundation of the nephrology in Colombia by the 1960s making clear that many of them, such as Doctor Jaime Borrero Ramírez in Medellín and Mora himself in Bogotá, already had stepped forward in the management of renal diseases in Colombia before going overseas to specialize.

The Colombian Nephrology Society, presently Colombian Association of Nephrology and Hypertension was created in 1966 in Bogotá. From the HMC group and its graduates, Doctors José María Mora Ramírez, Hernán Torres Iregui, Eduardo Carrizosa Alajmo, Roberto D'Achiardi Rey and Germán Gamarra Hernández were presidents of the Society.

\section{Nephrology at Hospital Militar Central of Bogotá}

The Division of Nephrology at HMC, the first created in the country, was initiated by Dr. José María Mora who was its chief between 1962 and 1970 when he was designated chief of the Department of Internal Medicine. He was substituted by Hernán Torres, also trained in nephrology at Cleveland Clinic, who took the leadership of the Division from 1970 to 1977 when was designated chief of the Internal Medicine Department.

In 1973, Torres created the two-year training program in nephrology at $\mathrm{HMC}$, homologated by the Colombian Society of Nephrology when the specialty wasn't even acknowledged in Colombia. Indeed, by that time the Society of Nephrology granted us the diploma as members of number, credential that was used for practicing nephrology in Colombia.

In 1975, Eduardo Carrizosa was graduated, becoming the first certified nephrologist trained in Colombia who was called to create the specialty and, in turn, he created the third school of nephrology of the country in 1981 at Hospital Universitario San José with the Universidad del Rosario, presently with the Fundación Universitaria de Ciencias de la Salud.

In 1978, Juan Daniel Ordoñez Ordoñez, trained in nephrology at Louisiana State University, who came from Charity Hospital New Orleans, was designated chief of the Nephrology Division and took the leadership up to 1981 when he returned to the United States to join the Kayser Foundation in Oakland, California. In 1977, the second nephrologist of the HMC School obtained his degree:

Roberto D'Achiardi, who joined the Nephrology Division of the institution and then obtained his nephrology fellowship at Cincinnati General Hospital and University of Cincinnati with Victor Pollak; he came back in 1982 as chief of the HMC's nephrology division. By 1982, the specialty at HMC and the Militar School of Medicine were licensed by Ascofame, the first nephrology specialty licensed in Colombia. In March 1988, he moved to the Hospital Universitario San Ignacio and Pontificia Universidad Javeriana to lead on the nephrology division, and in the same year he created the fifth nephrology school of the country, officially licensed in 1990.

The second School of nephrology at Hospital San Vicente de Paúl of Medellin, with the Universidad de Antioquia was created in 1975 by Jaime Borrero.

The fourth school was founded in the Hospital Universitario del Valle with the Universidad del Valle, by Álvaro Mercado Juri.

The other three nephrology postgraduate programs were created as stated below: the sixth school in 1998 at Hospital Clínica San Rafael with Juan N. Corpas School of Medicine by Mauricio Sanabria Arenas, graduated from the HMC's School; the seventh school at Fundación Cardioinfantil with Universidad del Rosario in 1999 by Jesús Muñoz Silva, and the last one by Mauricio Uribe Betancur in Medellín in 2001, at Clínica Universitaria Bolivariana presently Hospital Pablo Tobón Uribe with Pontificia Universidad Bolivariana.

Retaking the history of the HMC's Division of Nephrology, from 1988 to nearby 2000, Dr. María Elvira Martínez Rondanelli took the leadership of the Division and then she was designated scientific assistant director at HMC being substituted by Manuel Ruiz in the direction. Finally, since 2008, the renal unit operates in agreement with Baxter, being inaugurated a modern renal unit in January 19, 2009. Between 2007 and 2009, the Division has been headed by Hildebrando Leguizamón Sendoya, nephrologist graduated from Universidad Javeriana and José Manuel Arboleda Vallecillas, graduated from HMC. 
Since July 2010, the Division of Nephrology is being headed by Jorge Echeverri Sarmiento, graduated from Pontificia Universidad Javeriana and Hospital Universitario San Ignacio, with postgraduate studies in 2009 in Critical Care at Austin Hospital, in Melbourne, with Rinaldo Bellomo; Dr. Juan Guillermo Vargas, also graduated from Universidad Javeriana, is his assistant.

\section{Graduated Nephrologists}

At the beginning, the nephrologists were trained at HMC which is the Medical Center of Graduate Studies, and years later, after the official licensing of graduate degree in nephrology in the country, at the Militar School of Medicine, presently Universidad Militar Nueva Granada.

Forty eight nephrologists have been graduated; following Eduardo Carrizosa and Roberto D'Achiardi, they were in an orderly fashion: Germán Gamarra, Germán Durán, Álvaro Ordóñez, Gustavo Aroca, Carlos Prada, Ramón Duque, Luis Castillo, Hernando Giovanetti, John Serna, Andrés Díaz, Mauricio Sanabria, Enrique Klahr, Martha Medina, Robert Briceño, Rafael Rodríguez, Hernando González, Mauricio Nieto, Iván Nieto, Manuel Soto, Armando Ramos, Ignacio Villanueva, Amalfi Charry, Erika Yama, Amable Durán, Andrés Soto, David Camargo, Yelma Osorio, Layla Tamer, Amauri Ariza, Manuel Ruiz, Edgar Tinjacá, Jorge Van Arken, José Manuel Arboleda, Luis Cano, Luis A Cely, Elkin Machacón, Jesús Morales, Edwin Hernandez, Jose Javier Ayala, Fredis Miguel Baloco, Jorge Antonio Mora, Sonia Celis, Fabián Barrios, Rodrigo Daza, Mario Javier Serna and César Mercado. All of them have their nephrology practices within the highest scientific, ethical and personal standards in various cities of the country. Currently, 4 fellows are being trained: Mauricio Moreno, Gustavo Quiróz, Jaime Echenique and Alejandro Camargo.

\section{Pediatric Nephrology}

The development of pediatric nephrology at HMC was in a certain way in tandem with the adult nephrology and has played an important role in the country. The Division was created by Jorge de la Cruz París in 1961, after receiving training in Mexico with Gustavo Gordillo Paniagua; subsequently, de la Cruz trained Erika Cuervo who was chief of the Division between
1977 and 1980 being substituted by Ricardo Gastelbondo Amaya, also trained in Mexico by Gordillo, who took the leadership form 1980 to 2000 when he left, being replaced by Oscar Hernández Rodríguez who is in charge up to this day.

Gastelbondo founded the first Pediatric Nephrology School in Colombia with Universidad del Bosque at Fundación Cardioinfantil, which was licensed in 2000 and accepted residents as from 2002, being the first one Luz Stella González. Then, almost simultaneously, the Pediatric Nephrology School was created in Medellín by Juan José Vanegas at Hospital Pablo Tobón Uribe with Pontificia Universidad Bolivariana.

\section{Acute Peritoneal Dialysis}

Within the formal establishment of clinical nephrology in Colombia, José María Mora performed in 1962 the first acute peritoneal dialysis (APD) at HMC, modality of therapy that was used routinely from that time on in patients with acute renal insufficiency, by that time with the standard technique, rigid catheter, open system, using dialysis fluid bottled and then contained in plastic bags with Travenol technology. Since that time, other hospital institutions in the country started the program using the same technique up to end of the 1980s when the pharmaceutical companies stopped manufacturing rigid catheters which contributed to the abandonment of APD until recent years when this therapeutic option is getting to be used in ARI based on the same devices used for chronic peritoneal dialysis (CPD) which is being performed once again at HMC since 2008.

It should be noted that in Colombia, the first APDs with "paisa" technology were done in Medellín in 1960 by Álvaro Toro Mejía and Jaime Borrero.

\section{Chronic Peritoneal Dialysis}

The CPD in the mode of continuous ambulatory peritoneal dialysis (CAPD), was initiated at Hospital San Vicente de Paúl of Medellín by Jaime Borrero's group in March 1981, and several months later by the groups of Eduardo Carrizosa at Hospital San José and Roberto D'Achiardi at HMC of Bogotá. Next, it started to become routine therapy for the management of chronic renal disease patients in the country. Since 1994, we have the automated peritoneal dialysis (APD). In 2008, the prevalence of 
CPD patients was 6478 . With a population higher than $46,294,841$, it is estimated that near 22,000 patients are on chronic dialysis from which around $40 \%$ receive CPD.

\section{Acute Hemodialysis}

Mora brought the first Kolff artificial kidneys to Colombia for HMC and Clínica Shaio of Bogotá. $\mathrm{He}$ performed the first acute hemodialysis (HD) in Colombia on a teenager, who nowadays is a Cardiologist, who had ARI following an aortic coarctation surgery at Clínica Shaio in June 1963. In this first procedure he was assisted by Dr. Gustavo Restrepo, Cardiologist, who had received temporary training in nephrology at Cleveland Clinic while he was awaiting the initiation of his Cardiology postgraduate program. As an anecdotic fact, not being the water suitable for the dialysis performance, it was necessary to call the fire truck which provided the best quality water for that time and location through a second floor window, being necessary for the fire truck to wait up for two hours in order to provide the water for the second exchange. The above because in that time, the tank was filled from the "pot", as was popularly called the Kollf kidney, with 120 liters which were to be exchanged two hours later in order to complete the four-hour dialysis.
At HMC, Mora performed the first acute HD on August 6, 1963, in a sixth floor room diagonal to his office, equipped for this purpose, site where many acute hemodialyses were performed (Figure 1) until the renal unit was inaugurated on the second floor of the hospital. Then, Enrique Carvajal Arjona and his group at Hospital San Juan de Dios of Bogotá and Jaime Borrero and Álvaro Toro at San Vicente de Paúl of Medellín did the same.

By this time, once the decision of performing the dialysis was made, the nephrologist placed surgically the Schribner shunt, usually in the forearm, which got coagulated or infected with relative facility. Subsequently, and for several years two vascular catheters placed by puncture in the femoral vein were used, which were removed after each procedure, and even were reused some times by leaving them into a formol solution and years later into cidex in the intermediate period. The dialysis solution for Kollf kidney was prepared based on 120 liters of water to which salt $600 \mathrm{~g} /$ liter, sugar $750 \mathrm{~g} /$ liter, bicarbonate 250 $\mathrm{g} /$ liter, potassium chloride, calcium and magnesium were added, that is, a "whole cooking recipe", which next was mixed with a plastic stick. If by mistake the order of the ingredients placement was altered, these elements became precipitated and it was necessary to empty the tank and start again. Upon two hours of the acute $\mathrm{HD}$, the tank was emptied and the dialysis

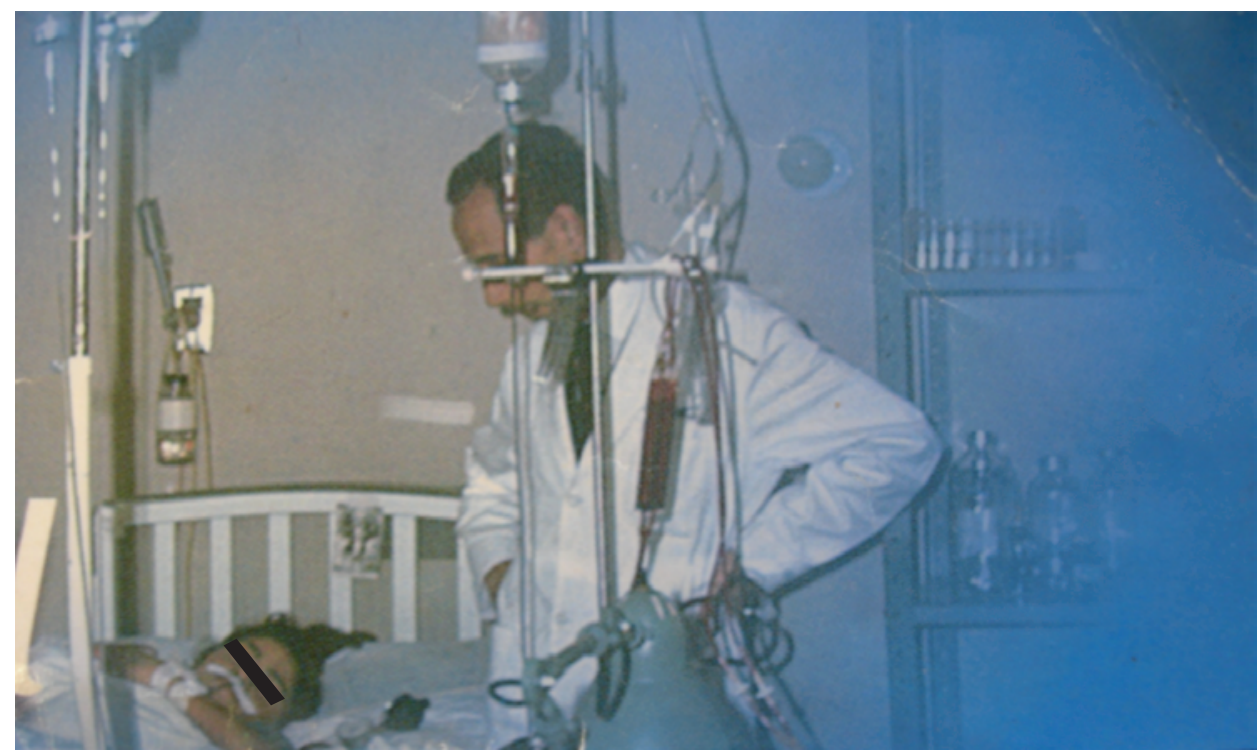

Figure 1. Acute hemodialysisperformed at HMC of Bogotá in the 1960s by Dr. José María Mora. 
solution was to be prepared for the two remaining hours.

Usually, the patient was connected at 7:00 AM and the dialysis was ending by 12:00 midnight, in the early times with no nurse help. Upon ending, the catheters were removed and the artificial kidney was cleaned. The above mentioned makes contrast with the current management of the acute renal insufficiency with modern technology, being its treatment with acute HD a routine which will persist over time, with increasingly better technology along with the various current therapeutic options of continuous renal replacement (CRRT).

\section{Continuous Renal Replacement Therapies}

in addition to the routine management of acute renal insufficiency patient with acute HD and APD, currently several modes of CRRT are available such as continuous venovenous hemofiltration, high-volume hemofiltration, hemodiafiltraton, isolated ultrafiltration, of which various procedures had already been performed at HMC, but which at present, specially since 2010 headed by Jorge Echeverri, are being performed routinely with more than 200 procedures per year. Similarly, other types of techniques of extracorporeal clearance are being used at HMC in patients with autoimmune pathologies, as it is the case with plasmapheresis or plasma interchange with more than 50 interventions performed in the last year.

\section{Chronic Hemodialysis}

Between 1956 and 1960 the chronic hemodialysis (HD) as a mode of therapy for chronic renal disease became widespread, favored by inventions such as the Schribner shunt in 1960 and the Brescia and Cimino arteriovenous fistula in 1964 in New York.

In Colombia, the chronic HD was initiated by 1967 in Medellin. Over there, the GRACEC (after the names Graciela and Cecilia, the first patients who used it) kidney was designed; likewise, at Hospital San Juan de Dios of Bogotá, followed by Torres at HMC of Bogotá in 1971, institution where as an anecdotic data, an artificial kidney built in Colombia by the engineer Jorge Reynolds for a relative who was on home dialysis was used temporarily.
Currently, in the Renal Unit at HMC there are available 28 points for state-of-the art technology artificial kidneys, performing chronic dialysis and follow-up for around 160 patients per month.

\section{Renal Transplant}

In 1953, the Hamburger group accomplished the first related donor transplant in París and in June 1954 the Merrill group performed the first identical twins transplant in Boston.

In Colombia, the pioneer of kidney transplant was Enrique Carvajal Arjona and his group at Hospital San Juan de Dios of Bogotá, who performed in 1965 the first four cadaveric transplants in Colombia. Later, the first kidney transplant regular program was created at Hospital San Vicente de Paúl of Medellí by Borrero, Toro and Jorge Luis Arango Acosta's Group who performed the first kidney transplant on August 29, 1973. This group continues actively trasplanting and has had the assistance of Mario Arbeláez Gómez, Gonzalo Mejía and Jorge Henao, among others, over time.

In 1978 the second program of kidney transplant in the country was created at HMC, with Torres, Mora, D'Achiardi and Ordoñez, being the vascular surgeons Víctor Caicedo Ayerbe, Wilde Jiménez Urbano and Gilberto Clavijo Contreras, and the urologists Jesús Guzmán Charry and Jaime Cajigas Rodríguez, multidisciplinary team that worked organized and efficiently for about 10 years up to 1988 .

The first cadaveric transplant was performed urgently in a weekend to a football referee who was becoming quadriparetic due to neuropathy secondary to chronic renal disease, who after some complications was discharged and had a functional kidney for several years. Later on, other transplant groups were created in Colombia which have performed more than 3500 transplants all over the country.

\section{Predialysis Consultation}

When that mode of care was not used in the regular clinical practice, there existed for many years a hypertension clinic created by Torres at HMC, which operated during several years, and currently, there is the predialysis consultation clinic providing services 
to near 200 patients, making contributions to the general practitioners and residents training by giving education about renal health promotion, prevention and CRD treatment in all its stages.

\section{Bibliography}

Borrero J. Apuntes a la historia de la nefrología en Colombia. Comunicación personal. No publicado. 1999.

Carvajal E. Alotrasplantes renales. Revista Médica, Órgano de la Academia Nacional de Medicina 1967; 3 - 18.

D'Achiardi R, Latorre J. El Trasplante renal. Revista Javeriana 1988; 551: $45-51$.
D'Achiardi R. Sociedad Colombiana de Nefrología y la especialidad en Colombia. Boletín ACMI. 1992; 4: 2.

D'Achiardi R. Reseña histórica de la nefrología en Colombia. Boletín Sociedad Colombiana Nefrología. 1992; 1:1 - 3.

D'Achiardi R, Mora JM, La nefrología en Colombia, pasado, presente y futuro. En Perspectivas en Nefrología, C López y H Altahona, editores; Editorial Ex Libris, Primera edición, 2000 pp $1-24$

D'Achiardi R. José María Mora Ramírez MD, FACP. Padre de la nefrología en Colombia. Revista Colombiana de Nefrología e Hipertensión Arterial 2008; 1: 256 - 257.

Gamarra G. Unidad de Nefrología. Revista UIS Medicina 1987; 15: 49 - 50.

Klahr S. The early days of the nephrology in Colombia. Kidney Int; 2006; 69: 199 - 200. 


\title{
EDITORIAL
}

\section{A NEFROLOGIA NO HOSPITAL MILITAR CENTRAL DE BOGOTÁ: 50 ANOS}

\author{
JoRGE ECHEVERRI SARMIENTO, MD ${ }^{1}$ \\ JUAN GUILLERMO VARGAS; $M D^{2}$ \\ ROBERTO D'ACHIARDI REY, MD, FAC ${ }^{3}$
}

\begin{abstract}
${ }^{1}$ Internista - Nefrologista Universidade Javeriana. Fellowship em Nefrologia Crítica, Hospital de Austin, Melbourne. Especialista em Medicina Crítica e Cuidado Intensivo, Fundação Universitária Sanitas. Chefe do Serviço de Nefrologia do Hospital Militar Central e da Unidade Renal Baxter - HMC. Nefrologista e Coordenador de Nefrologia Crítica do Hospital Universitário San Ignacio. Professor de Medicina da Universidade Militar Nueva Granada e da Pontifícia Universidade Javeriana. Bogotá

${ }^{2}$ Internista - Nefrologista Universidade El Bosque e Universidade Javeriana. Epidemiologista Clínico, Universidade El Bosque. Especialista, Serviço de Nefrologia, Hospital Militar Central e Unidade Renal Baxter - HMC. Professor de medicina da Universidade Militar Nueva Granada e da Universidade El Bosque. Bogotá.

${ }^{3}$ Internista - Nefrologista: Universidade do Rosário, Universidade Militar Nueva Granada, Universidade de Cincinnati. Nefrologista da Fundação Clínica Shaio. Nefrologista da Fundação Cardioinfantil e da Unidade Renal Baxter Cardioinfantil.

Professor Titular de Medicina da Universidade Javeriana. Professor Clínico Principal da Universidade de la Sabana.
\end{abstract}

\section{Introdução:}

Em 2012 o serviço de nefrologia do Hospital Militar Central (HMC) de Bogotá completa cinquenta anos de criação, e para comemorar esta data fizemos uma revisão da história da nefrologia no $\mathrm{HMC}$ e o alto impacto que tem tido no desenvolvimento da nefrologia na Colômbia.

O serviço de nefrologia do HMC foi criado em 1962, pelo mestre e professor José María Mora Ramírez, vinculado ao hospital desde 1955 como chefe do serviço de medicina interna e depois de realizar treinamento em nefrologia em Cleveland com Willem Wolff, pai do rim artificial.

De acordo com isso, durante essas cinco décadas, o serviço e quem o tem integrado, tem sido diretriz e baluarte no desenvolvimento da nefrologia colombiana, sobra a qual exerceram profunda influência $e$ tem formado grande numero de nefrologistas, que exercem a especialidade no país.

\section{Começo da nefrologia na Colômbia}

Para localizar dentro do contexto mundial e nacional o começo da nefrologia no HMC de Bogotá em 1962, devemos lembrar que a especialidade nasceu como disciplina cientifica em 1960, durante o Primeiro Congresso Internacional de Nefrologia em Evian, França. $\mathrm{Na}$ América do Norte, depois do desenvolvimento lento da nefrologia nos anos 40, foi definida como especialidade independente na metade dos anos 50 e nasceu como subespacialidade com a criação da National Kidney Foundation em 1960.

De forma quase simultânea, na década de 60, iniciouse a nefrologia como subespecialidade na Colômbia. Oito internistas colombianos foram treinados em nefrologia nessa época nos Estados Unidos e no México e voltaram à Colômbia para criar a subespacialidade. Um dos primeiros polos de desenvolvimento da nefrologia foi o HMC de Bogotá, sob a direção de Mora.

Mora contatou à Kolff como resultado de sua visita à Colômbia como professor visitante na Clínica Shaio em 1961, almejando realizar um curso na área de nefrologia. Isso se converteu em um feito, resultando no felowship na área de nefrologia, sob a direção de Kolff, no Departamento de Órgãos Artificiais na Cleveland Clinic Foundation e Western Reserve University. Ele regressou à Colômbia em 1962 para ser o criador e primeiro chefe do departamento de nefrologia do HMC, e tornar-se então, 
em nossa opinião, o pai de nefrologia na Colômbia. Poucos meses ou anos mais tarde, chegaram outros especialistas a fim de criar o Serviço de nefrologia do Hospital San Juan de Dios, em Bogotá, San Vicente de Paúl em Medellín, e da Universidade del Valle, este último em 1965. Três cidades, quatro centros hospitalares, e oito nefrologistas famosos foram a base estrutural da nefrologia na Colômbia na década de 60, sendo evidente que muitos deles, como o Dr. Jaime Ramirez Borrero em Medellín e mesmo o Dr. Mora em Bogotá, já tinham dado passos na direção dos cuidados das doenças renais na Colômbia, antes de ir fazer sua especialização. A Sociedade Colombiana de Nefrologia, hoje conhecida como Associação Colombiana de Nefrologia e Hipertensão Arterial , foi criada em 1966, em Bogotá. Do grupo do HMC e dos seus formandos, foram presidentes da Sociedade os doutores José María Mora Ramirez, Hernán Torres Iregui, Carrizosa Eduardo Alajmo, Roberto D’Achiardi Rei e Hernández Germán Gamarra.

\section{Nefrologia no Hospital Militar Central em Bogotá}

O departamento de nefrologia do $\mathrm{HMC}$, o primeiro criado no país, foi inaugurado por José Maria Mora, que foi chefe deste departamento entre 1962-1970, quando foi nomeado chefe do departamento de medicina interna. Ele foi substituído por Hernan Torres, que também cursou nefrologia na Clínica Cleveland e que atuou como chefe do serviço entre os anos de 1970-1977, mais tarde ele foi nomeado chefe do departamento de medicina interna.

Em 1973, Torres criou o programa de treinamento em Nefrologia no HMC, com dois anos de duração, validado pela Sociedade Colombiana de Nefrologia, quando a especialidade ainda não era reconhecida na Colômbia. Na verdade, naquela época, a Sociedade de Nefrologia nos outorgava o diploma como membro de número, que era o documento utilizado para o exercício da nefrologia na Colômbia.

Eduardo Carrizosa formou-se em 1975, sendo o primeiro nefrologista diplomado na Colômbia, que foi chamado para criar a especialidade e, por sua vez, criou a terceira escola de Nefrologia no país em 1981 no Hospital Universitário San José com a Universidade del Rosario, agora com a Fundação Universitária de Ciências da Saúde.
Em 1978 foi nomeado chefe do Serviço de Nefrologia, Juan Daniel Ordoñez Ordoñez, treinado em Nefrologia na Louisiana State University, que veio do Charity Hospital New Orleans, e manteve a liderança até 1981, quando ele retornou aos Estados Unidos para trabalhar com a Fundação Kayser em Oakland, Califórnia.

Em 1977, formou-se o segundo nefrologista da Escola HMC: Roberto D'Achiardi, que juntou-se ao departamento de Nefrologia da instituição e, em seguida, realizado o Fellowship em Nefrologia no Hospital Geral de Cincinnati e da Universidade de Cincinnati com Victor Pollak, retornando em 1982 como chefe do departamento de nefrologia do HMC. Em 1982 foi aprovada a especialidade da HMC e da Escola Militar de Medicina da ASCOFAME, e foi assim a primeira especialidade de Nefrologia aprovada na Colômbia. Em março de 1988 foi para o Hospital Universitário San Ignacio e para a Pontifícia Universidade Javeriana, para dirigir o departamento de Nefrologia, e nesse mesmo ano criou a quinta escola de Nefrologia do país, aprovada oficialmente em 1990.

A segunda escola de Nefrologia no Hospital San Vicente de Paúl, em Medellín, com a Universidade de Antioquia, foi criada em 1975 por Jaime Borrero.

A quarta escola foi criada no Hospital Universitário del Valle com a Universidad del Valle, por Alvaro Mercado Juri.

As outras pós-graduações de nefrologia do país foram criadas assim: a sexta escola en 1998 no Hospital Clínica San Rafael com a Escola de Medicina Juan N. Corpas por Mauricio Sanabria Arenas, formado pela escola do HMC; a sétima escola na Fundação Cardioinfantil com a Universidad del Rosario em 1999 por Jesús Muñoz Silva e a última, por Mauricio Uribe Betancur Medellín em 2001, na Clínica Universitária Bolivariana, hoje no Hospital Pablo Tobón Uribe com a Pontifícia Universidade Bolivariana.

Continuando com a história do serviço de nefrologia do HMC, desde 1988 até 2000 ocupou a chefia do serviço María Elvira Martínez Rondanelli, depois nomeada subdiretora científica do HMC, sendo substituída na direção por Manuel Ruiz. Finalmente, desde 2008 a unidade renal funciona em convênio com a Baxter, sendo inaugurada uma moderna unidade renal em 19 de janeiro de 2009. Foram chefes do 
serviço entre 2007 e 2009 Hildebrando Leguizamón Sendoya, nefrologista formado pela Universidade Javeriana e José Manuel Arboleda Vallecillas, formado pelo HMC.

Desde julho de 2.010 o serviço de nefrologia é dirigido por Jorge Echeverri Sarmiento, formado pela Pontifícia Universidade Javeriana e pelo Hospital Universitário San Ignacio, com estudos de pós-graduação em 2009 em Cuidado Crítico no Hospital de Austin, em Melbourne, com Rinaldo Bellomo; com a colaboração de Juan Guillermo Vargas, também formado pela Universidade Javeriana.

\section{Nefrologistas formados}

No principio os nefrologistas se formaram no HMC, que é Centro Médico de Estudos para Graduados e anos depois, após a aprovação oficial da pós-graduação em nefrologia no país, com a Escola Militar de Medicina, hoje Universidade Militar Nueva Granada.

Formaram-se 48 nefrologistas depois de Eduardo Carrizosa e Roberto D'Achiardi, formaram-se por ordem Germán Gamarra, Germán Durán, Álvaro Ordóñez, Gustavo Aroca, Carlos Prada, Ramón Duque, Luis Castillo, Hernando Giovanetti, John Serna, Andrés Díaz, Mauricio Sanabria, Enrique Klahr, Martha Medina, Robert Briceño, Rafael Rodríguez, Hernando González, Mauricio Nieto, Iván Nieto, Manuel Soto, Armando Ramos, Ignacio Villanueva, Amalfi Charry, Erika Yama, Amable Durán, Andrés Soto, David Camargo, Yelma Osorio, Layla Tamer, Amauri Ariza, Manuel Ruiz, Edgar Tinjacá, Jorge Van Arken, José Manuel Arboleda, Luis Cano, Luis A Cely, Elkin Machacón, Jesús Morales, Edwin Hernandez, Jose Javier Ayala, Fredis Miguel Baloco, Jorge Antonio Mora, Sonia Celis, Fabián Barrios, Rodrigo Daza, Mario Javier Serna e César Mercado. Todos eles exercem a nefrologia com os mais altos padrões científicos, éticos e pessoais em diversas cidades do país. Encontram-se atualmente em treinamento 4 fellows: Mauricio Moreno, Gustavo Quiróz, Jaime Echenique e Alejandro Camargo.

\section{Nefrologia Pediátrica}

O desenvolvimento da nefrologia pediátrica no Hospital Militar Central foi, de certa forma, paralelo ao da nefrologia de adultos e tem desempenhado um papel importante no país. O serviço foi criado por Jorge de la Cruz París em 1961, após o seu treinamento no México com Gustavo Gordillo Paniagua; em seguida, Cruz treinou Erika Cuervo, que foi chefe do serviço entre 1977 e 1980, sendo depois substituída por Ricardo Gastelbondo Amaya, também treinado no México por Gordillo, que foi chefe desde 1980 até 2000 , quando se aposentou, sendo substituído por Oscar Hernández Rodríguez, que permanece a cargo do serviço até hoje.

Gastelbondo fundou a primeira escola de nefropediatria da Colômbia, com a Universidade El Bosque na Fundação CardioInfantil, que foi aprovada no ano 2000 e recebeu médicos residentes a partir de 2002, sendo a primeira Luz Stella González. Depois de forma quase simultânea foi criada a escola de nefropediatria em Medellín, por Juan José Vanegas, no Hospital Pablo Tobón Uribe, com a Pontifícia Universidade Bolivariana.

\section{Diálise peritoneal aguda}

Como parte do estabelecimento formal da nefrologia clínica na Colômbia, José María Mora realizou, em 1962 a primeira diálise peritoneal aguda (DPA) no $\mathrm{HMC}$, uma modalidade de terapia que continuou sendo realizada rotineiramente em pacientes com insuficiência renal aguda, nessa época utilizando a técnica padrão, com cateter rígido e sistema aberto, utilizando o líquido de diálise em garrafas, passando depois a utilizar bolsas plásticas, com a tecnologia Travenol. Desde essa época, outras instituições hospitalares do país iniciaram o programa, utilizando a mesma técnica, até o final dos anos 80 , quando as companhias farmacêuticas pararam de produzir cateteres rígidos, o que contribuiu para o abandono da DPA, até recentemente, quando se voltou a utilizar esta opção terapêutica em casos de Insuficiência Renal Aguda, com base nas mesmas soluções utilizadas para a diálise peritoneal crônica (DPC), que está novamente se realizando no HMC desde 2008.

Note-se que na Colômbia, as primeiras DPAs foram realizadas no ano de 1960, em Medellín, por Álvaro Toro Mejía e Toro Jaime Borrero.

\section{Diálise peritoneal crônica}

A DPC na forma de diálise peritoneal ambulatorial contínua (DPAC) foi iniciada no Hospital San Vicente de Paúl, em Medellín, pela equipe de Jaime Borrero 
em Março de 1981, e vários meses mais tarde, pelas equipes de Eduardo Carrizosa no Hospital San José e de Roberto D'Achiardi no HMC em Bogotá. A partir de então, rapidamente tornou-se uma terapia de rotina no país para o tratamento de pacientes com doença renal crônica. Fazemos diálise peritoneal automatizada (DPA) desde 1994. Em 2008, a população de pacientes prevalentes em DPC era de 6478. Com uma população superior a 46294841 habitantes, estima-se que atualmente possam existir cerca de 22 000 pacientes em diálise crônica, dos quais cerca de 40\% recebem DPC.

\section{Hemodiálise aguda}

Mora trouxe os primeiros rins artificiais Kolff para a Colômbia, para o HMC e para a Clínica Shaio, em Bogotá. Na Colômbia, a primeira hemodiálise aguda (HDA) foi realizada em um adolescente, hoje cardiologista, que apresentou insuficiência renal aguda (IRA) depois de uma cirurgia de aorta na Clínica Shaio em junho de 1963. O cardiologista Gustavo Restrepo colaborou no primeiro procedimento, tendo recebido um treinamento transitório em nefrologia em Cleveland, antes de iniciar a pós-graduação em cardiologia. Curiosamente, não sendo a água apta para fazer diálise, foi necessário chamar o carro de bombeiros que forneceu a água de melhor qualidade para a época e região através de uma janela do segundo andar, tendo o veículo aguardado duas horas para fornecer a água para a troca seguinte. Isso, porque naquele tempo enchia-se o tanque da "panela", termo popular para designar o rim de Kolff, com 120 litros, sendo necessário trocá-los após duas horas para completar quatro horas de diálise.

Mora realizou sua primeira HDA no HMC em 6 de agosto de 1963, em uma sala no sexto andar na frente de seu escritório, equipada para esse fim, espaço onde se realizaram muitas hemodiálises agudas (Figura 1) até ter sido inaugurada a unidade renal no segundo andar do hospital. Posteriormente foram realizadas por Enrique Carvajal Arjona e sua equipe no Hospital San Juan de Dios em Bogotá e Jaime Alvaro Borrero y Toro no San Vicente de Paúl, em Medellín.

Nessa época, uma vez decidida a diálise, o nefrologista colocava cirurgicamente o shunt de Scribner, geralmente no antebraço, que coagulava e se infectava com relativa facilidade. Posteriormente, e durante vários anos, utilizaram-se dois cateteres vasculares colocados por punção na veia femoral, que eram retirados após cada procedimento e inclusive reutilizados várias vezes, sendo deixados em solução de formol e posteriormente em cidex, por um determinado tempo. A solução de diálise para o rim de Kolff era preparada com base em 120 litros de água à qual se adicionava $600 \mathrm{~g}$ de sal / litro, $750 \mathrm{~g}$ de açúcar / litro, $250 \mathrm{~g}$ de

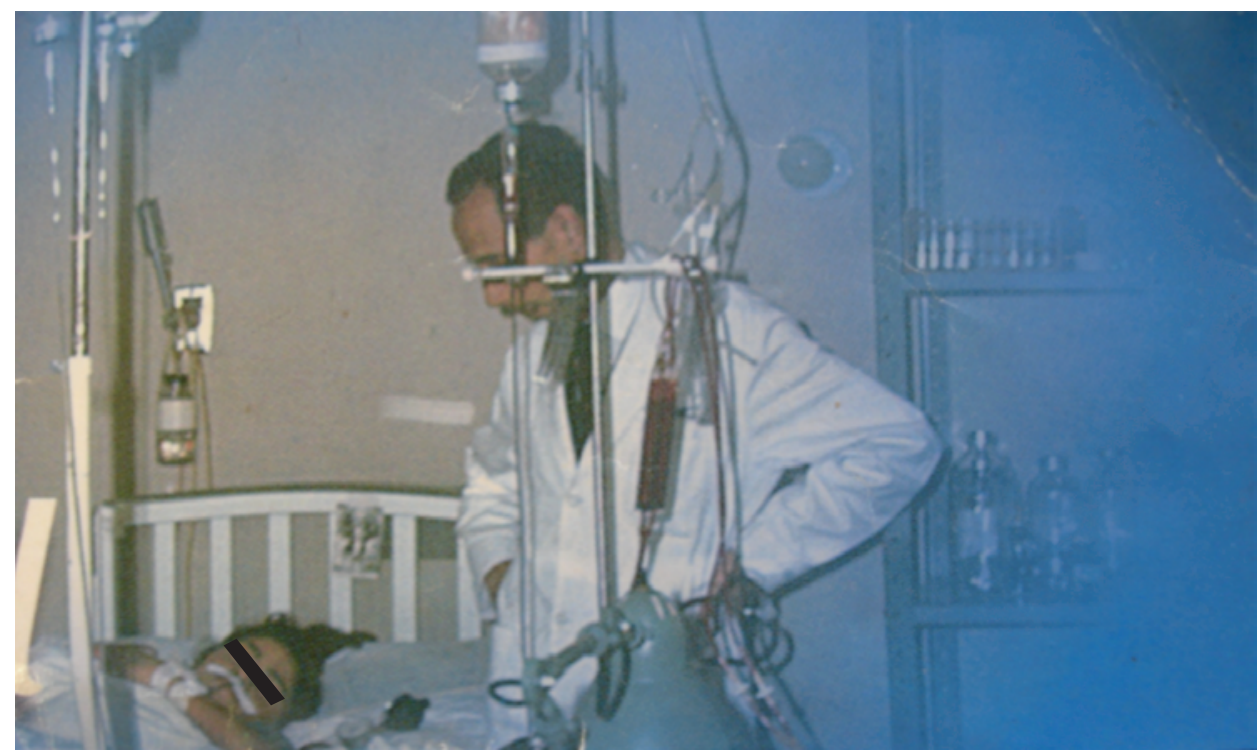

Figura 1. Hemodiálise aguda realizada no HMC de Bogotá nos anos sessenta pelo Dr. José María Mora. 
bicarbonato / litro, cloreto de potássio, cálcio e magnésio, ou seja, "uma completa receita de cozinha" e que então se misturavam com uma vareta de plástico. Se por engano a ordem de colocação dos ingredientes fosse alterada, estes elementos se separavam sendo necessário esvaziar o reservatório e começar de novo. Após duas horas de HDA, se esvaziava o reservatório e se preparava novamente a solução de diálise para as duas horas seguintes.

O paciente era ligado normalmente por volta das $7 e$ se concluía a diálise após as 12 da noite, a princípio sem a colaboração da equipe de enfermagem. Após o término removiam-se os cateteres e se efetuava a limpeza do rim artificial. O que foi dito anteriormente contrasta com o gerenciamento atual da insuficiência renal aguda, com tecnologia moderna, sendo seu tratamento com HDA uma rotina que persistirá através do tempo com tecnologia cada vez melhor, juntamente com as diferentes opções terapêuticas atuais de terapias de substituição renais contínuas (TSRC).

\section{Terapias de Substituição Renal Contínuas}

Além do tratamento rotineiro do paciente com insuficiência renal aguda com HDA e DPA, atualmente se dispõe de diversas modalidades de TSRC, como hemofiltração venovenosa contínua, hemofiltração de alto volume, hemodiafiltração e ultrafiltração isolada. Vários desses procedimentos já tinham sido realizados no HMC, mas hoje em dia e principalmente desde 2010, sob a direção de Jorge Echeverri, estão sendo realizados rotineiramente, com mais de 200 procedimentos ao ano. Da mesma forma, vem sendo utilizado outro tipo de técnicas de depuração extracorpórea nos pacientes do $\mathrm{HMC}$ com patologias autoimunes. Esse é o caso da plasmaferese ou intercâmbio plasmático, com mais de 50 intervenções no último ano.

\section{Hemodiálise crônica}

Entre 1956 e 1960 a hemodiálise crônica (HDC) se generalizou como modalidade de terapia para a doença renal crônica, favorecida por invenções como o shunt de Schribner em 1960 e a fístula arteriovenosa de Brescia e Cimino em 1964, em Nova Iorque.

Na Colômbia, a HDC se iniciou em 1967, em Medellín. Além disso, lá foi desenvolvido o rim GRACEC (Graciela e Cecilia), devido ao nome das duas primeiras pacientes que o utilizaram. $\mathrm{O}$ mesmo aconteceu no Hospital San Juan de Dios de Bogotá, seguido por Torres no HMC de Bogotá em 1971 - instituição onde, como curiosidade, foi utilizado transitoriamente um rim artificial feito na Colômbia pelo engenheiro Jorge Reynolds para um conhecido que fazia diálise em casa.

Hoje em dia, na Unidade Renal do HMC, dispõe-se de 28 pontos para rins artificiais de última tecnologia que realizam a diálise crônica e o acompanhamento de cerca de 160 pacientes por mês.

\section{Transplante renal}

Em 1953, o grupo de Hamburgo realizou o primeiro transplante de doador compatível em Paris e, em junho de 1954, o grupo de Merrill foi responsável pelo primeiro transplante de gêmeos idênticos em Boston.

Na Colômbia, Enrique Carvajal Arjona e equipe, no Hospital San Juan de Dios de Bogotá, foram os pioneiros na realização de transplante renal, quando, em 1965, realizaram os quatro primeiros transplantes de cadáver na Colômbia. Pouco tempo depois, foi criado o primeiro programa regular de transplante renal no Hospital San Vicente de Paúl de Medellín, pela equipe de Borrero, Toro e Jorge Luis Arango Acosta, que realizaram o primeiro transplante renal, em 29 de agosto de 1973. Atualmente, equipe permanece ativa na realização de transplantes e, ao longo do tempo, obteve a colaboração de Mario Arbeláez Gómez, Gonzalo Mejía e Jorge Henao, entre outros.

Em 1978 foi criado o segundo programa de transplante renal do país, no HMC, com a participação de Torres, Mora, D'Achiardi e Ordoñez, fazendo parte do grupo os cirurgiões vasculares Victor Caicedo Ayerbe, Wilde Jiménez Urbano e Gilberto Clavijo Contreras, bem como os urologistas Jesús Guzmán Charry e Jaime Cajigas Rodríguez, equipe multidisciplinar que trabalhou de forma organizada e eficiente durante cerca de 10 anos, até 1988.

O primeiro transplante de cadáver foi realizado de emergência, em um final de semana, em um juiz de futebol que estava se tornando quadriparético por neuropatia secundária decorrente da doença renal crônica. Após algumas complicações, o paciente deixou o hospital com um rim funcional que o acompanhou por muitos anos. Posteriormente, foram criados outros grupos de transplante na Colômbia, 
que foram responsáveis pela realização de mais de 3.500 transplantes em âmbito nacional.

\section{Consulta pré-diálise}

No HMC existiu por muitos anos, quando esse modelo de atendimento não era utilizado na prática clínica regular, uma clínica de hipertensão arterial criada por Torres, que funcionou durante vários anos, e atualmente, existe a clínica de consulta prédiálise que atende aproximadamente 200 pacientes, contribuindo com a formação de médicos gerais $e$ residentes com educação em temas de promoção de saúde renal, prevenção e tratamento da ERC em todos seus estágios.

\section{Bibliografia}

Borrero J. Apuntes a la historia de la nefrologia en Colombia. Comunicação pessoal. Não publicado. 1999

Carvajal E. Alotrasplantes renales. Revista Médica, Órgano de la Academia Nacional de Medicina 1967; 3 - 18.

D'Achiardi R, Latorre J. El Trasplante renal. Revista Javeriana 1988; 551: 45 - 51.

D'Achiardi R. Sociedad Colombiana de Nefrología y la especialidad en Colombia. Boletín ACMI. 1992; 4: 2.

D'Achiardi R. Reseña histórica de la nefrologia en Colombia. Boletín Sociedad Colombiana Nefrología. 1992; 1:1 - 3.

D'Achiardi R, Mora JM, La nefrologia en Colombia, pasado, presente y futuro. En Perspectivas en Nefrología, C López y H Altahona, editores; Editorial Ex Libris, Primeira edição, 2000 pp $1-24$.

D’Achiardi R. José María Mora Ramírez MD, FACP. Padre de la nefrologia en Colombia. Revista Colombiana de Nefrología y Hipertensión Arterial 2008; 1: 256 - 257.

Gamarra G. Unidade de Nefrología. Revista UIS Medicina 1987; 15: $49-50$.

Klahr S. The early days of the nephrology in Colombia. Kidney Int; 2006; 69: 199 - 200. 